\title{
PERBEDAAN MASALAH PSIKOSOSIAL ANTARA ANAK OBESITAS DAN GIZI NORMAL DI SD NEGERI 1 BANDA SAKTI KOTA LHOKSEUMAWE
}

\author{
Mayang Sukma Marevia ${ }^{1}$, Mauliza ${ }^{2}$, Cut Asmaul Husna ${ }^{3}$ \\ ${ }^{1}$ Mahasiswa Fakultas Kedokteran, Universitas Malikussaleh, \\ Uteunkot, Lhokseumawe, 24352, Indonesia \\ 2 Bagian Anak, Fakultas Kedokteran, Malikussaleh University, \\ Uteunkot, Lhokseumawe, 24352, Indonesia \\ ${ }^{3}$ Bagian Mikrobiologi,Fakultas Kedokteran,Malikussaleh University, \\ Uteunkot, Lhokseumawe, 24352, Indonesia \\ Corresponding Author : mayangsukmamarevia13@gmail.com
}

\begin{abstract}
Abstrak
Obesitas pada anak merupakan peningkatan berat badan melebihi batas kebutuhan skeletal dan fisik akibat akumulasi lemak secara berlebihan dalam tubuh. Salah satu indeks antropometri yang digunakan untuk menentukan status gizi obesitas dan gizi normal adalah Indeks Massa Tubuh (IMT)/umur. Obesitas dan gizi normal masing-masing dikategorikan bila IMT CDC $2000>$ P95 dan P5$<$ P85. Obesitas pada anak berhubungan dengan masalah psikososial seperti penurunan kualitas hidup yang signifikan, risiko lebih besar untuk diintimidasi dan isolasi sosial serta anak menarik diri dari lingkungan sosial. Penelitian bertujuan untuk mengetahui perbedaan masalah psikososial antara anak obesitas dan gizi normal di SD Negeri 1 Banda Sakti Kota Lhokseumawe, menggunakan kuesioner Pediatric Symptom Checklist (PSC)-17. Jenis penelitian bersifat analitik dengan pendekatan cross sectional dan metode purposive sampling dengan total 88 orang (44 anak obesitas dan 44 anak gizi normal. Uji Chi Square menunjukkan terdapat perbedaan masalah psikososial antara anak obesitas dan gizi normal di SD Negeri 1 Banda Sakti Kota Lhokseumawe $(p=0,015)$.

Kata Kunci: Masalah Psikososial; Obesitas; Pediatric Symptom Checklist (PSC)-17.
\end{abstract}




\title{
DIFFERENT OF PSYCHOSOCIAL PROBLEMS BETWEEN OBESE CHILDRENS AND THE CHILDRENS WITH NORMAL NUTRITIONAL STATUS ON SD NEGERI 1 BANDA SAKTI LHOKSEUMAWE
}

\begin{abstract}
Obesity in children is a condition when the increase of body weight exceed the skeletal and physical requirement that caused the accumulation of fat excessively in the body. Body Mass Index (BMI)/age is one of antropometry's parameters to determine nutritional status of someone is in obese or normal category. The nutritional status called obese or normal when BMI CDC $2000>$ P95 and P5-<P85. Obesity in children related to psychosocial problems such as significant decrease from quality of life, higher chance to receive intimidation also social isolation and social withdrawal. This study was aimed to observe the different between psychosocial problems between obese childrens and the childrens with normal nutritional status on SD Negeri 1 Banda Sakti Lhokseumawe, by using Pediatric Symptom Checklist (PSC)-17. This was an analytical study with cross sectional approach and purposive sampling method with 88 samples (44 obese childrens and 44 childrens with normal nutritional status). The Chi Square's test result showed that there is different of psychosocial problems between obese childrens and the childrens with normal nutritional status on SD Negeri 1 Banda Sakti Lhokseumawe $(\mathrm{p}=0,015)$.
\end{abstract}

Key words: Obesity; Psychosocial problems; Pediatric Symptom Checklist (PSC)-17. 


\section{Pendahuluan}

Obesitas telah menjadi masalah kesehatan di seluruh dunia. World Health Organization (WHO) menyebutkan bahwa obesitas merupakan epidemik global dan masalah kesehatan yang harus ditangani. ${ }^{1}$ Obesitas merupakan keadaan patologis, yaitu terdapatnya penimbunan lemak berlebihan yang diperlukan untuk fungsi tubuh yang normal. ${ }^{2}$ Angka kejadian obesitas pada masa kanak-kanak meningkat secara cepat di seluruh dunia. ${ }^{3}$ Umumnya penyebab yang mendasari adalah anak-anak menghabiskan lebih banyak waktu di depan televisi, komputer, atau perangkat video game daripada bermain di luar ruangan. Tipikal keluarga yang saat ini sangat sibuk dan hanya mempunyai sedikit waktu untuk menyiapkan makanan sehari-hari, sehingga banyak yang memilih makanan cepat saji yang biasanya tinggi kalori dan rendah nilai gizinya. ${ }^{4}$

Selama 3 dekade terakhir prevalensi overweight dan obesitas telah meningkat serta diperkirakan 170 juta anak-anak $(<18$ tahun) mengalami overweight dan obesitas. ${ }^{1}$ Secara global diperkirakan 42 juta anak usia $<5$ tahun mengalami overweight dan obesitas pada tahun 2013. Angka ini akan terus meningkat dan diperkirakan pada tahun 2025 terdapat 70 juta anak usia $<5$ tahun yang mengalami overweight dan obesitas. ${ }^{3}$

Penelitian yang dilakukan di Indonesia menunjukkan bahwa anak yang berusia $<10$ tahun memiliki risiko sebesar 3,8 kali mengalami obesitas dibandingkan anak usia $\geq 10$ tahun. ${ }^{5}$ Prevalensi obesitas pada usia 5 sampai 12 tahun secara nasional masih tinggi, yaitu sebesar $8 \%$, usia 13 sampai 15 tahun sebesar 2,5\%, dan usia 16 sampai 18 tahun sebesar $1,6 \%$. Prevalensi obesitas di Provinsi Aceh usia 5 sampai 12 tahun adalah $6 \%$, sedangkan usia 13 sampai 15 tahun dan 16 sampai 18 tahun masing-masing adalah $2 \%$ dan $1 \%$.
Obesitas pada anak berhubungan dengan penurunan kualitas hidup yang signifikan dan risiko yang lebih besar untuk menerima intimidasi dan isolasi sosial. Obesitas yang dialami anak tersebut akan mengantarkannya pada masalah yang menyangkut perkembangan sosial dan emosional anak, seperti percaya diri yang rendah dan memiliki kemampuan sosialisasi yang lebih rendah daripada anak dengan berat badan normal, sehingga menyebabkan anak tersebut menarik diri dari pergaulan sosial. Isolasi sosial dan rendahnya rasa percaya diri menimbulkan rasa tidak berdaya pada sebagian anak obesitas dan akhirnya menyebabkan depresi. ${ }^{4}$

Prevalensi obesitas tertinggi untuk provinsi Aceh adalah berada pada usia Sekolah Dasar (SD). ${ }^{6}$ Pada tahap ini anak akan mengembangkan pola industri (produktif) versus inferioritas (rendah diri). Perkembangan utama pada tahap ini adalah menanamkan interaksi yang sesuai dengan teman sebaya, khususnya di sekolah. Rasa rendah diri akan muncul jika dalam proses interaksi tidak tercapai harapan yang diinginkan. ${ }^{7}$

Sekolah Dasar Negeri 1 Banda Sakti adalah salah satu SD yang memiliki siswa terbanyak di Kota Lhokseumawe. Berdasarkan observasi data awal peneliti dari 109 siswa, didapatkan penghasilan orang tua yang sangat tinggi $12 \%$, tinggi $30 \%$, sedang $38 \%$, dan rendah $20 \%$. Selain itu, didapatkan $74 \%$ memiliki jumlah saudara 0 sampai 2 orang dan $26 \%$ memiliki jumlah saudara $>3$ orang. ${ }^{8}$

Tujuan penelitian ini adalah untuk menganalisis perbedaan masalah psikososial antara anak obesitas dan gizi normal di SD Negeri 1 Banda Sakti Kota Lhokseumawe, khususnya adalah untuk mengetahui distribusi frekuensi pendapatan, pendidikan, pekerjaan orang tua, dan jumlah saudara kandung pada anak obesitas dan gizi normal, mengetahui gambaran masalah psikososial pada anak obesitas, mengetahui 
gambaran masalah psikososial pada anak gizi normal serta mengetahui perbedaan masalah psiksosial antara anak obesitas dan gizi normal di SD Negeri 1 Banda Sakti Kota Lhokseumawe.

\section{Metode}

Penelitian ini merupakan penelitian analitik dengan rancangan potong lintang (cross sectional study). Penelitian ini dilaksanakan di SD Negeri 1 Banda Sakti Kota Lhokseumawe mulai bulan Oktober sampai Januari 2015. Populasi dalam penelitian ini adalah seluruh siswa-siswi SD Negeri 1 Banda Sakti Kota Lhokseumawe, yaitu sebanyak 638 anak. Sampel dalam penelitian ini adalah siswa-siswi SD Negeri 1 Banda Sakti yang memenuhi kriteria inklusi dan kriteria eksklusi. Kriteria inklusinya adalah berstatus sebagai siswasiswi SD Negeri 1 Banda Sakti, berusia 6 sampai 13 tahun, hadir pada saat penelitian dilakukan, Orang tua/wali bersedia menjadi responden, anak obesitas serta anak gizi normal, baik laki-laki atau perempuan yang diukur status gizinya dan diklasifikasikan berdasarkan IMT/U CDC 2000. Sementara kriteria eksklusi dalam penelitian ini adalah anak menderita penyakit kronik (thalassemia, tuberkulosis, dan lainnya), mengalami kelainan kongenital dan mempunyai riwayat orang tua tunggal atau berpenyakit mental.

Sampel diambil dengan menggunakan teknik purposive sampling. Berdasarkan perhitungan besar sampel dengan menggunakan rumus 2 proporsi, maka besar sampel yang dibutuhkan dalam masing-masing kelompok adalah 37 anak dan jumlah sampel yang dibutuhkan seluruhnya adalah 74 anak dan dibulatkan menjadi 80 anak.

Instrumen yang digunakan dalam penelitian ini terdiri dari, instrumen lembar persetujuan dan identitas diri, timbangan berat badan digital merk Gea ketelitian 100 gram, mikrotoa (microtoise) merk Gea ketelitian $1 \mathrm{~mm}$ dan kuesioner. Kuesioner yang digunakan adalah Pediatric Symptom Checklist-17 (PSC-17). PSC-17 merupakan suatu kuesioner skrining yang digunakan untuk menilai gangguan psikologis meliputi gangguan pada aspek internalisasi, eksternalisasi, dan perhatian. PSC-17 merupakan modifikasi dari Pediatric Symptom Checklist-35 (PSC-35), yaitu salah satu alat skrining yang telah distandarisasi, digunakan untuk anak usia 4-18 tahun. PSC17 terdiri atas 17 pertanyaan yang dibagi dalam menjadi subskala internalisasi terdiri atas 5 pertanyaan, subskala eksternalisasi 7 pertanyaan, dan subskala perhatian 5 pertanyaan. Masing-masing pertanyaan tersebut memiliki skor 0 , 1, dan 2. Skor masing-masing subskala tersebut dijumlahkan dan jumlah skor tersebut dijadikan skor total, dicurigai terdapat masalah psikososial jika jumlah skor internalisasi $\geq 5$, jumlah skor eksternalisasi $\geq 7$, jumlah skor perhatian $\geq 7$, atau skor total $\geq 15$. Kuesioner ini telah di validasi serta dapat digunakan sebagai alat skrining masalah psikososial pada anak dengan sensitivitas $69,2 \%$ dan spesifisitas $95,6 \%{ }^{9}$

Data primer dalam penelitian ini adalah data dari hasil pengukuran berat badan dan tinggi badan masing-masing anak. Apabila anak memenuhi kriteria penelitian, maka peneliti akan melakukan pendekatan lebih lanjut pada keluarga responden dengan menjelaskan tentang tujuan dan manfaat penelitian yang akan dilakukan melalui informed consent serta diikuti oleh pengisian kuesioner penelitian yang dibagikan oleh peneliti kepada orang tua/wali siswa-siswi SD Negeri 1 Banda Sakti yang telah memenuhi kriteria yang telah ditentukan peneliti. 


\section{Hasil Penelitian}

Tabel 1. Distribusi Frekuensi Berdasarkan Umur dan Jenis Kelamin

\begin{tabular}{cllllll}
\hline Karakteristik & \multicolumn{2}{c}{ Obesitas } & \multicolumn{2}{c}{ Gizi Normal } & \multicolumn{2}{c}{ Total } \\
\cline { 2 - 6 } & $\mathbf{N}$ & $\mathbf{\%}$ & $\mathbf{n}$ & $\mathbf{\%}$ & $\mathbf{n}$ & $\mathbf{\%}$ \\
\hline Umur & & & & & & \\
\hline 6 tahun & 4 & 50 & 4 & 50 & 8 & 100 \\
7 tahun & 8 & 50 & 8 & 50 & 16 & 100 \\
8 tahun & 3 & 50 & 3 & 50 & 6 & 100 \\
9 tahun & 8 & 50 & 8 & 50 & 16 & 100 \\
10 tahun & 9 & 50 & 9 & 50 & 18 & 100 \\
11 tahun & 10 & 50 & 10 & 50 & 20 & 100 \\
12 tahun & 2 & 50 & 2 & 50 & 4 & 100 \\
13 tahun & 0 & 0 & 0 & 0 & 0 & 0 \\
\hline Jenis kelamin & & & & & & 100 \\
Laki-laki & 23 & 50 & 23 & 50 & 46 & 100 \\
Perempuan & 21 & 50 & 21 & 50 & 42 & \\
\hline
\end{tabular}

Berdasarkan tabel di atas, Berdasarkan jenis kelamin responden responden obesitas dan gizi normal terbanyak berada pada umur 11 tahun yaitu masing-masing sebanyak 10 orang (50\%). obesitas dan gizi normal lebih banyak didapatkan pada laki-laki yaitu 23 orang (50\%) dan perempuan 21 orang (50\%).

Tabel 2. Karakteristik Berat Badan, Tinggi Badan, dan Indeks Massa Tubuh

\begin{tabular}{lll}
\hline Variabel & \multicolumn{1}{c}{ Nilai $(\mathbf{n}=\mathbf{8 8})$} & \multicolumn{1}{c}{ Gizi Normal } \\
\cline { 2 - 3 } & \multicolumn{1}{c}{ Obesitas } & $26,877(17,8-42,8)$ \\
\hline Berat Badan $\mathbf{( k g )}$ & $45,973(26,2-71,8)$ & $129,925(114,0-154,5)$ \\
Tinggi Badan (cm) & $135,318(133,3-158,6)$ & $15,698(13,7-18,9)$ \\
Indeks Massa Tubuh $\mathbf{( k g / m ^ { 2 } )}$ & $24,652(19,9-31,5)$ &
\end{tabular}

Keterangan: nilai yang ditampilkan dalam bentuk mean

Berdasarkan tabel di atas, berat badan rerata anak obesitas adalah $45,973 \mathrm{~kg}$, dengan berat badan yang paling rendah 26,2 $\mathrm{kg}$ dan berat badan paling tinggi $71,8 \mathrm{~kg}$. Anak gizi normal memiliki rerata berat badan $26,877 \mathrm{~kg}$, berat paling rendah $17,8 \mathrm{~kg}$ dan berat badan paling tinggi $42,8 \mathrm{~kg}$. Berdasarkan tinggi badan, anak obesitas memiliki rerata $135,318 \mathrm{~cm}$, paling rendah didapatkan 133,3 cm dan paling tinggi didapatkan 158,6 cm. Anak gizi normal memiliki rerata tinggi badan adalah 129,925 $\mathrm{cm}$, paling rendah didapatkan $114 \mathrm{~cm}$ dan paling tinggi didapatkan 154,5 cm. Indeks Massa Tubuh rerata anak obesitas dan gizi normal adalah 24,652 $\mathrm{kg} / \mathrm{m}^{2}$ dan 15,698 $\mathrm{kg} / \mathrm{m}^{2}$, IMT tertinggi $18,9 \mathrm{~kg} / \mathrm{m}^{2}$, IMT terendah $13,7 \mathrm{~kg} / \mathrm{m}^{2}$.

Tabel 3. Karakteristik Jumlah Saudara Kandung

\begin{tabular}{llc}
\hline Variabel & \multicolumn{2}{l}{ Nilai $(\mathbf{n}=\mathbf{8 8})$} \\
\cline { 2 - 3 } & Obesitas & Gizi Normal \\
\hline Jumlah saudara kandung (orang) & $1,95(0-4)$ & $1,98(0-6)$ \\
\hline
\end{tabular}

(Sumber: Data primer, 2016) Keterangan: nilai yang ditampilkan dalam bentuk mean 
Berdasarkan tabel di atas, jumlah saudara kandung rerata anak obesitas adalah 1,95 , paling rendah 0 atau tidak memiliki saudara kandung dan paling banyak memiliki saudara kandung 4 orang.
Anak gizi normal memiliki jumlah saudara kandung rerata adalah 1,98 , paling rendah 0 atau tidak memiliki saudara kandung, dan paling banyak memiliki saudara kandung 6 orang.

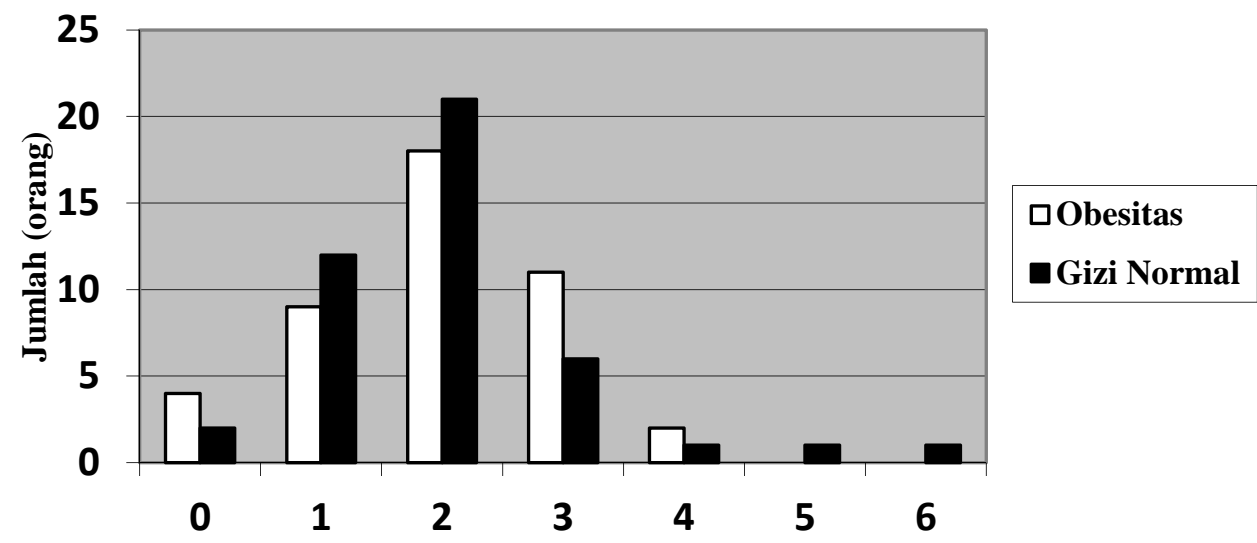

Gambar 1. Jumlah saudara kandung (orang)

Berdasarkan gambar di atas, responden obesitas dan gizi normal paling banyak memiliki jumlah saudara kandung 2 yaitu 18 orang $(46,2 \%)$ pada anak obesitas dan 21 orang $(53,8 \%)$ pada anak gizi normal, sedangkan paling rendah yaitu dengan jumlah saudara 5 dan 6 yang hanya didapatkan pada anak gizi normal.

Tabel 4. Distribusi Frekuensi Berdasarkan Karakteristik Orang Tua

\begin{tabular}{lllllll}
\hline Karakteristik orang tua & \multicolumn{2}{c}{ Obesitas } & \multicolumn{2}{c}{ Gizi Normal } & \multicolumn{2}{c}{ Total } \\
\cline { 2 - 7 } & $\mathbf{N}$ & $\mathbf{0}$ & $\mathbf{n}$ & $\mathbf{\%}$ & $\mathbf{n}$ & $\%$ \\
\hline Pendidikan terakhir ayah & & & & & & \\
SD & 0 & 0 & 1 & 100 & 1 & 100 \\
SMP & 0 & 0 & 2 & 100 & 2 & 100 \\
SMA & 20 & 44,4 & 25 & 55,6 & 45 & 100 \\
PT & 24 & 60 & 16 & 40 & 40 & 100 \\
\hline Pendidikan terakhir ibu & & & & & & \\
SMP & 1 & 100 & 0 & 0 & 1 & 100 \\
SMA & 18 & 46,2 & 21 & 53,8 & 39 & 100 \\
PT & 25 & 52,1 & 23 & 47,9 & 48 & 100 \\
\hline Pekerjaan ayah & & & & & & \\
PNS & 20 & 43,5 & 26 & 56,5 & 46 & 100 \\
Pegawai swasta & 10 & 66,7 & 5 & 33,3 & 15 & 100 \\
Wiraswasta & 13 & 56,5 & 10 & 43,5 & 23 & 100 \\
Buruh/tukang & 1 & 25 & 3 & 75 & 4 & 100 \\
\hline
\end{tabular}




\begin{tabular}{lllllll}
\hline Pekerjaan ibu & & & & & & \\
PNS & 14 & 43,8 & 18 & 56,2 & 32 & 100 \\
Pegawai swasta & 4 & 57,1 & 3 & 42,9 & 7 & 100 \\
Wiraswasta & 5 & 71,4 & 2 & 28,6 & 7 & 100 \\
IRT & 21 & 50 & 21 & 50 & 42 & 100 \\
\hline Penghasilan orang tua & & & & & & \\
Rendah & 1 & 14,3 & 6 & 85,7 & 7 & 100 \\
Sedang & 3 & 37,5 & 5 & 62,5 & 8 & 100 \\
Tinggi & 8 & 61,5 & 5 & 38,5 & 13 & 100 \\
Sangat tinggi & 32 & 53,3 & 28 & 46,7 & 60 & 100 \\
\hline
\end{tabular}

Berdasarkan tabel di atas, pendidikan terakhir ayah responden obesitas paling banyak di perguruan tinggi sebanyak 24 orang (60\%). Pendidikan terakhir ibu responden obesitas dan gizi normal paling banyak di perguruan tinggi, yaitu 25 orang (52,1\%) pada anak obesitas dan 23 orang $(47,9)$ pada anak gizi normal. Pekerjaan ayah responden obesitas paling banyak didapatkan sebagai PNS, yaitu 20 orang $(43,5 \%)$ pada anak obesitas dan 26 orang $(56,5 \%)$ pada gizi normal. Sementara pekerjaan ibu responden paling banyak adalah sebagai ibu rumah tangga dan didapatkan sebanding sebanyak 21 orang (50\%) pada responden obesitas dan gizi normal. Penghasilan orang tua didapatkan umumnya memiliki orang tua berpenghasilan sangat tinggi sebanyak 60 orang $(100 \%)$, yaitu 32 orang $(53,3 \%)$ pada obesitas dan 28 orang $(46,7)$ pada gizi normal.

Tabel 5. Distribusi Frekuensi Berdasarkan Masalah Psikososial

\begin{tabular}{llc}
\hline Masalah psikososial & \multicolumn{2}{c}{ Jumlah } \\
\cline { 2 - 3 } & N & $\%$ \\
\hline Ya & 23 & 26,1 \\
\hline Tidak & 65 & 73,9 \\
\hline Total & 88 & 100 \\
\hline
\end{tabular}

Berdasarkan tabel di atas, responden mengalami masalah psikososial sebanyak 23 orang $(26,1 \%)$, sedangkan yang tidak mengalami masalah psikososial sebanyak 65 orang $(73,9 \%)$.

Tabel 6. Distribusi Frekuensi Masalah Psikososial Berdasarkan Umur dan Jenis Kelamin

\begin{tabular}{|c|c|c|c|c|c|c|}
\hline \multirow{3}{*}{ Karakteristik } & \multicolumn{4}{|c|}{ Masalah psikososial } & \multirow{2}{*}{\multicolumn{2}{|c|}{ Total }} \\
\hline & \multicolumn{2}{|c|}{ Ya } & \multicolumn{2}{|c|}{ Tidak } & & \\
\hline & $\mathbf{n}$ & $\%$ & $\mathbf{n}$ & $\%$ & $\mathbf{n}$ & $\%$ \\
\hline Umur & & & & & & \\
\hline 6 tahun & 2 & 25 & 6 & 75 & 8 & 100 \\
\hline 7 tahun & 7 & 43,8 & 9 & 56,2 & 16 & 100 \\
\hline 8 tahun & 2 & 33,3 & 4 & 66,7 & 6 & 100 \\
\hline 9 tahun & 4 & 25 & 12 & 75 & 16 & 100 \\
\hline 10 tahun & 3 & 16,7 & 15 & 83,3 & 18 & 100 \\
\hline 11 tahun & 3 & 15 & 17 & 85 & 20 & 100 \\
\hline 12 tahun & 2 & 50 & 2 & 50 & 4 & 100 \\
\hline 13 tahun & 0 & 0 & 0 & 0 & 0 & 0 \\
\hline
\end{tabular}




\begin{tabular}{|l|l|l|l|l|l|l|l|}
\hline Jenis kelamin & & & & & & \\
Laki-laki & 11 & 23,9 & 35 & 76,1 & 46 & 100 \\
Perempuan & 12 & 28,6 & 30 & 71,4 & 42 & 100 \\
\hline
\end{tabular}

Berdasarkan tabel di atas, responden mengalami masalah psikososial tertinggi didapatkan pada umur 7 tahun sebanyak 7 orang $(43,8 \%)$. Sementara berdasarkan jenis kelamin lebih banyak didapatkan pada perempuan dibandingkan laki-laki, yaitu 12 orang $(28,6 \%)$ pada perempuan dan 11 orang $(23,9 \%)$ pada laki-laki.

Tabel 7. Perbedaan Masalah Psikososial antara Anak Obesitas dan Gizi Normal

\begin{tabular}{|c|c|c|c|c|c|c|c|}
\hline \multirow[t]{3}{*}{ Status Gizi } & \multicolumn{4}{|c|}{ Masalah Psikososial } & \multirow{2}{*}{\multicolumn{2}{|c|}{ Total }} & \multirow[t]{3}{*}{ p value } \\
\hline & \multicolumn{2}{|c|}{$\mathrm{Ya}$} & \multicolumn{2}{|c|}{ Tidak } & & & \\
\hline & $\mathrm{n}$ & $\%$ & $\mathrm{~N}$ & $\%$ & $\mathrm{~N}$ & $\%$ & \\
\hline Obesitas & 17 & 38,6 & 27 & 61,4 & 44 & 100 & 0,015 \\
\hline Gizi Normal & 6 & 13,6 & 38 & 86,4 & 44 & 100 & \\
\hline Total & 23 & 26,1 & 65 & 73,9 & 88 & 100 & \\
\hline
\end{tabular}

Berdasarkan tabel di atas, jumlah siswa SD Negeri 1 Banda Sakti mengalami masalah psikososial sebanyak 23 orang $(26,1 \%)$, yaitu 17 orang responden obesitas $(38,6 \%)$ dan 6 orang responden gizi normal (61,4\%). Uji statistik diperoleh $\mathrm{p}$ value sebesar 0,015 $(\mathrm{a}=0,05)$, yang berarti Ho ditolak, sehingga terdapat perbedaan masalah psikososial antara anak obesitas dan gizi normal di SD Negeri 1 Banda Sakti Kota Lhokseumawe.

Tabel 8. Aspek Masalah Psikososial Anak Obesitas dan Gizi Normal

\begin{tabular}{|c|c|c|c|c|c|c|}
\hline \multirow[t]{3}{*}{ Aspek Psikososial } & \multicolumn{4}{|c|}{ Status Gizi } & \multirow{2}{*}{\multicolumn{2}{|c|}{ Total }} \\
\hline & \multicolumn{2}{|c|}{ Obesitas } & \multicolumn{2}{|c|}{ Gizi Normal } & & \\
\hline & $\mathbf{n}$ & $\%$ & $\mathrm{n}$ & $\%$ & $\mathbf{n}$ & $\%$ \\
\hline \multicolumn{7}{|l|}{ Internalisasi } \\
\hline Ya & 10 & 71,4 & 4 & 28,6 & 14 & 100 \\
\hline Tidak & 34 & 45,9 & 40 & 54,1 & 74 & 100 \\
\hline \multicolumn{7}{|l|}{ Eksternalisasi } \\
\hline Ya & 10 & 83,3 & 2 & 16,7 & 12 & 100 \\
\hline Tidak & 34 & 44,7 & 42 & 55,7 & 76 & 100 \\
\hline \multicolumn{7}{|l|}{ Perhatian } \\
\hline Ya & 2 & 100 & 0 & 0 & 2 & 100 \\
\hline Tidak & 42 & 48,8 & 44 & 51,2 & 86 & 100 \\
\hline
\end{tabular}

Berdasarkan tabel di atas, responden obesitas didapatkan sebanyak 10 orang $(71,4 \%)$ mengalami masalah internalisasi, sedangkan gizi normal sebanyak 4 orang $(28,6 \%)$. Responden yang mengalami masalah eksternalisasi sebanyak 12 orang $(100 \%)$, yaitu 10 orang $(83,3 \%)$ responden obesitas dan 2 orang $(16,7 \%)$ responden gizi normal. Masalah perhatian dialami 2 orang $(100 \%)$ anak obesitas.

\section{Pembahasan}

Penelitian dilakukan di SD Negeri 1 Banda Sakti Kota Lhokseumawe didapatkan secara kumulatif usia anak obesitas lebih 
banyak berada pada kelompok umur 6 sampai 9 tahun dibandingkan 10 sampai 13 tahun. Hal ini sejalan dengan penelitian di Kota Medan didapatkan $56,3 \%$ berusia 6 sampai 9 tahun dan $43,7 \%$ berusia 10 sampai 13 tahun. ${ }^{10}$ Penelitian Sartika didapatkan $72,9 \%$ anak obesitas berusia $<10$ tahun dan $27,1 \%$ berumur $\geq 10$ tahun. $^{5}$ Penelitian yang dilakukan di Padang didapatkan $63,4 \%$ anak obesitas berusia 6 sampai 9 tahun dan $36,6 \%$ berusia 10 sampai 12 tahun. ${ }^{11}$ Anak usia tersebut merupakan kelompok yang rentan terhadap gizi lebih. Kebutuhan zat gizi terutama anak laki-laki usia $\geq 10$ tahun lebih besar dibandingkan anak perempuan karena pengaruh aktivitas fisik dan growth spurt anak laki-laki lebih besar, akibatnya

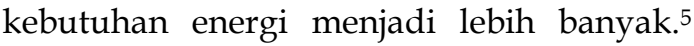
Menurut penelitian di India kejadian obesitas akan berkurang seiring dengan pertambahan usia karena munculnya sikap pemalu pada remaja yang pubertas dibandingkan dengan anak belum pubertas. $^{12}$

Hasil penelitian ini menunjukkan obesitas laki-laki lebih banyak didapatkan dari perempuan, yaitu 23 orang laki-laki dan 21 orang perempuan. Hal ini sejalan dengan penelitian di Kota Medan obesitas anak lakilaki dan perempuan didapatkan masingmasing $60,5 \%$ dan 39,5\%. ${ }^{10}$ Penelitian Sartika mendapatkan $57,3 \%$ obesitas pada anak lakilaki dan $42,7 \%$ pada anak perempuan. Anak laki-laki memiliki risiko mengalami obesitas sebesar 1,4 kali dibandingkan anak perempuan. Hal ini disebabkan anak perempuan lebih sering membatasi makan untuk alasan penampilan. ${ }^{5}$ Selain itu pola makan laki-laki cenderung lebih banyak mengkonsumsi makanan jajanan daripada anak perempuan, sehingga laki-laki lebih berkemungkinan menjadi obesitas daripada perempuan, ditambah dengan munculnya game playstation, sehingga anak laki-laki cenderung jarang memainkan permainan yang memerlukan kalori tinggi. ${ }^{13}$
Hasil penelitian ini menunjukkan rerata jumlah saudara kandung anak obesitas 1,94 dan anak obesitas 1,98, artinya jumlah saudara kandung anak obesitas dan gizi normal tidak menunjukkan perbedaan berarti. Hal ini sejalan dengan penelitian oleh Pujiastuti, Fadlyana, dan Garna bahwa jumlah saudara kandung obesitas dan gizi normal tidak menunjukkan perbedaan. ${ }^{14}$ Sementara jika dilihat pada masing-masing jumlah saudara kandung, anak obesitas memiliki 0 sampai 4 saudara kandung dan terbanyak dengan saudara kandung 2 orang, artinya semakin banyak jumlah saudara maka kejadian obesitas semakin berkurang. Hal ini disebabkan beban ekonomi keluarga menjadi lebih banyak, sementara jumlah anak mempengaruhi kesejahteraan keluarga. ${ }^{15}$

Hasil penelitian ini menunjukkan pendidikan terakhir ayah terbanyak didapatkan di perguruan tinggi sebanyak 24 orang $(60 \%)$, sedangkan anak gizi normal terbanyak di SMA sebanyak 25 orang $(55,6 \%)$, artinya anak obesitas umumnya memiliki ayah dengan pendidikan tinggi, sementara anak gizi normal umumnya pendidikan menengah. Sementara pendidikan ibu anak obesitas dan gizi normal terbanyak sama-sama didapatkan di perguruan tinggi, yaitu 25 orang (52,1\%) pada anak obesitas dan 23 orang $(47,9 \%)$ pada anak gizi normal. Hal ini sejalan dengan penelitian di Kota Bogor mendapatkan $80 \%$ anak obesitas memiliki ayah dan ibu riwayat pendidikan di perguruan tinggi. Tingkat pendidikan sangat berpengaruh terhadap perubahan sikap dan perilaku hidup. ${ }^{16}$

Pekerjaan ayah responden obesitas dan gizi normal terbanyak didapatkan sebagai PNS yaitu 20 orang $(43,5 \%)$ anak obesitas dan 26 orang $(56,5 \%)$ anak gizi normal. Pekerjaan ibu antara responden obesitas dan gizi normal didapatkan sebanding, yaitu sebagai ibu rumah tangga. Penelitian Permatasari, Mayulu, dan Hamel 
mendapatkan $29,4 \%$ pekerjaan ayah anak obesitas sebagai PNS. ${ }^{17}$

Menurut Atmarita \& Fallah tingkat pendidikan yang lebih tinggi akan memudahkan masyarakat untuk menyerap informasi dan mengimplementasikan dalam perilaku dan gaya hidup sehari-hari, khususnya dalam hal kesehatan dan gizi. Makin tinggi tingkat pendidikan maka pendapatan akan semakin tinggi. Pendapatan keluarga yang tinggi berarti kemudahan dalam membeli dan mengonsumsi makanan enak dan mahal yang mengandung energi tinggi seperti fast food. ${ }^{16}$

Penelitian ini menunjukkan penghasilan keluarga berdasarkan klasifikasi Badan Pusat Statistik didapatkan 32 dari 44 anak obesitas memiliki keluarga dengan pendapatan yang sangat tinggi (>3.500.000), sementara pada anak gizi normal didapatkan 28 dari 44 anak, artinya pendapatan yang sangat tinggi lebih banyak pada anak obesitas daripada anak gizi normal. Bannet mengemukakan peningkatan pendapatan akan mengakibatkan individu cenderung meningkatkan kualitas konsumsi pangannya dengan harga yang lebih mahal per unit zat gizinya. Peningkatan pendapatan berarti memperbesar peluang untuk membeli pangan dengan kualitas dan kuantitas yang lebih baik. Selain itu, menurut Nasoetion dan Riyadi keluarga yang berpenghasilan tinggi lebih mudah dalam menentukan pemilihan bahan pangan sesuai dengan syarat mutu yang baik. Pendapatan yang tinggi akan meningkatkan daya beli sehingga keluarga mampu membeli pangan dalam jumlah yang diperlukan dan berdampak positif terhadap status gizi. ${ }^{16}$

Penelitian ini mendapatkan masalah psikososial dialami sebanyak 23 orang $(26,1 \%)$, sedangkan tidak mengalami masalah psikososial sebanyak 65 orang (73,9\%). Masalah psikososial anak obesitas paling tinggi pada umur 7 tahun, sedangkan umur 13 tahun tidak didapatkan adanya masalah psiksosial. Hal ini disebabkan perilaku intimidasi teman sebaya obesitas mulai ditunjukkan sebelum anak memasuki sekolah dasar. ${ }^{18}$ Anak berumur 5 tahun sudah mulai menyadari obesitas berpengaruh terhadap penampilan, kemampuan atletik, kompetensi fisik, kompetensi sosial dan harga diri. ${ }^{19}$

Masalah psikososial dilihat berdasarkan jenis kelamin lebih banyak pada perempuan dibanding laki-laki, pada penelitian ini didapatkan laki-laki sebanyak 11 orang dan perempuan sebanyak 12 orang. Anak obesitas memiliki risiko tertentu untuk rendah harga diri. Beberapa studi menunjukkan anak obesitas memiliki harga diri yang rendah dibandingkan anak yang tidak obesitas. Harga diri pada anak obesitas bervariasi dengan jenis kelamin, umumnya perempuan berada pada risiko lebih besar terkena rendah diri dibandingkan dengan anak laki-laki. Selain itu, stigmatisasi yang terjadi lebih sering dan intens pada perempuan daripada laki-laki. ${ }^{19}$

Penelitian ini didapatkan persentase masalah psikososial lebih banyak dialami oleh anak obesitas dibandingkan anak gizi normal, yaitu 17 orang $(38,6 \%)$ anak obesitas dan 6 orang $(13,6 \%)$ anak gizi normal. Berdasarkan hasil analisis bivariat didapatkan $\mathrm{p}$ value 0,015 , Ho ditolak dan dapat diambil kesimpulan terdapat perbedaan masalah psikososial antara anak obesitas dan gizi normal di SD Negeri 1 Banda Sakti Kota Lhokseumawe.

Penelitian lainnya yang dilakukan pada 94 anak obesitas usia 6 sampai 12 tahun didapatkan masalah psikososial sebanyak 22\% atau didapatkan 21 anak obesitas mengalami masalah psikososial. ${ }^{9}$ Penelitian lainnya dilakukan pada 62 siswa SMP Negeri 14 Bandung dengan rentang usia 1216 tahun didapatkan responden obesitas lebih banyak mengalami masalah psikososial dibandingkan dengan 
responden gizi normal, dan didapatkan perbedaan yang bermakna. ${ }^{14}$

Anak obesitas lebih mudah mengalami gangguan psikososial termasuk gangguan hubungan dengan teman sebaya, kesejahteraan psikologis yang rendah, dan korban dalam berbagai bentuk intimidasi, baik dalam bentuk verbal (nama panggilan), fisik, atau melalui hubungan sehari-hari seperti pengucilan dari lingkungan sosial sekitarnya. ${ }^{20}$ Anak obesitas sering dikaitkan dengan sejumlah masalah psikososial seperti kualitas hidup yang rendah dan merasa rendah diri. Secara klinis anak obesitas menunjukkan depresi yang tinggi, kecemasan, masalah perilaku, dan perhatian Penelitian menunjukkan 30-60\% dari anak obesitas yang berusia 5 sampai 18 tahun dirujuk untuk pengobatan. ${ }^{19}$

Anak obesitas memiliki risiko tertentu untuk rendah harga diri. Studi menunjukkan anak obesitas memiliki harga diri yang rendah dibandingkan anak yang tidak obesitas. ${ }^{23}$ Anak obesitas sering mendapat ejekan dari orang tua dan anggota keluarga lain karena ukuran dan bentuk tubuh dan tanpa disadari orang tua, hal ini menyebabkan kerusakan terhadap harga diri anak tersebut. ${ }^{18}$ Perilaku intimidasi dapat merugikan korban intimidasinya termasuk sosial, emosional, dan status kesehatan fisik yang lebih buruk, serta secara serius menyebabkan terhambatnya perkembangan sosial anak. ${ }^{20}$

Gangguan psikososial pada anak obesitas dapat disebabkan oleh dua faktor, yaitu faktor internal dan eksternal. Faktor internal merupakan faktor yang berasal dari anak itu sendiri, yaitu merasa berbeda dengan anak lain atau keinginan untuk mengurus tubuh, sehingga anak obesitas mempunyai rasa percaya diri yang rendah, persepsi diri yang negatif serta adanya rasa rendah diri. Faktor eksternal merupakan faktor yang berasal dari lingkungan yang memberikan stigma tertentu pada anak obesitas seperti dianggap sebagai anak yang malas, bodoh, dan lamban. Lingkungan merupakan keseluruhan fenomena fisik dan sosial yang dapat mempengaruhi atau dipengaruhi perkembangan anak, teman sebaya, dan masyarakat. ${ }^{18}$

C.L. Fox menyebutkan ketidakpuasan penampilan fisik dan tubuh dapat bertindak sebagai mediator hubungan antara status berat badan dan intimidasi. ${ }^{20}$ Lerner mengusulkan teori untuk memahami hubungan antara penampilan fisik dan fungsi sosial. Teori tersebut menyatakan penampilan fisik mempengaruhi orang lain untuk bereaksi secara berbeda dalam lingkungan. ${ }^{18}$ Citra dan persepsi tubuh yang baik ditemukan berbanding terbalik dengan berat badan. Anak obesitas menampilkan lebih banyak gangguan citra tubuh dan sikap negatif yang lebih sering dibandingkan teman sebaya dengan berat badan normal. Beberapa penelitian menunjukkan ketidakpuasan tubuh memediasi hubungan antara obesitas dan harga diri dan didapatkan hasil yang signifikan yaitu anak obesitas dengan ketidakpuasan tubuh memiliki harga diri yang rendah. ${ }^{19}$

Stereotip merupakan konsep mengenai sifat suatu golongan berdasarkan prasangka yang bersifat subjektif dan belum tentu tepat. Stereotip sosial yang negatif untuk anak obesitas berperan penting dalam menyebabkan anak obesitas menjadi target untuk diintimidasi. Anak obesitas sering dicirikan oleh teman sebayanya sebagai anak yang jelek, bodoh, malas, egois, kecerdasan yang lebih rendah, isolasi sosial, fungsi sosial yang buruk, dan keberhasilan akademik rendah. ${ }^{18,19}$ Selain menjadi korban intimidasi, anak obesitas memungkinkan untuk menjadi pelaku intimidasi. Hal ini disebabkan karena sering diintimidasi serta ingin merasa superior dan kuat atas orang lain ketika mencoba untuk mengatasi perasaan rendah diri. ${ }^{18}$

Anak obesitas tidak selalu mengalami masalah psikososial. Penelitian ini 
didapatkan 27 dari 44 anak obesitas tidak mengalami masalah psikososial. Menurut Israel dan Ivanova beberapa anak obesitas mempunyai rasa percaya diri dan tidak merasa rendah diri seperti anak berat badan normal. Anak tersebut menggunakan metode kompensasi sebagai perlindungan terhadap timbulnya rasa percaya diri yang rendah. Metode kompensasi tersebut adalah discounting dan distortion. Discounting adalah menempatkan hal-hal yang merupakan kelebihan mereka di atas penilaian terhadap bentuk tubuhnya sendiri, sedangkan distortion merupakan meningkatkan persepsi mengenai kompetensi dengan mengesampingkan bentuk tubuh dan berat badan. Anak laki-laki dan perempuan obesitas tidak menekankan rasa percaya diri mengenai bentuk fisiknya, tetapi lebih menekankan rasa percaya diri mengenai hal lain untuk mempertahankan rasa percaya dirinya. ${ }^{14}$

Penelitian ini mendapatkan 6 dari 44 anak gizi normal mengalami masalah psikososial. Salah satu faktor yang mempengaruhi masalah psikososial adalah tipe kelompok primer (keluarga). Hal ini disebabkan karena pola asuh, seperti pola asuh yang otoriter (autoritarian). Pola asuh otoriter merupakan pengasuhan yang kaku, diktator dan memaksa anak untuk selalu mengikuti perintah orang tua tanpa banyak alasan. Pola asuh ini biasa ditemukan penerapan hukuman fisik dan aturan-aturan tanpa merasa perlu menjelaskan kepada anak kegunaan dan alasan di balik aturan tersebut. ${ }^{20}$ Sikap otoriter orang tua akan berpengaruh pada profil perilaku anak dan memberikan dampak buruk seperti anak menjadi agresif (mudah marah, tidak patuh, keras kepala), submissive (mudah tersinggung, pemalu, penakut, suka mengasingkan diri), sulit bergaul, dan pendiam. Dampak lain pola asuh otoriter adalah anak merasa tidak bahagia, tidak terlatih untuk berinisiatif, selalu tegang, tidak mampu menyelesaikan masalah (kemampuan problem solving yang buruk), kemampuan komunikasinya buruk, kurang berkembangnya rasa sosial dan keberaniannya untuk mengambil keputusan, gemar menetang, suka melanggar norma, kepribadian lemah dan menarik diri. ${ }^{19}$

Perkembangan utama yang harus dicapai pada saat anak memasuki usia sekolah adalah menanamkan interaksi yang sesuai dengan teman sebaya dan orang lain, meningkatkan kemampuan intelektual khususnya di sekolah. Untuk perkembangan emosional anak usia sekolah perlu diberikan kesempatan untuk belajar menerapkan peraturan dalam berinteraksi dengan orang lain di luar lingkungan keluarganya. Ketika memasuki stadium ini, krisis psikososial yang akan dihadapi anak adalah industri versus inferioritas, jika dalam tahap ini dilalui dengan baik, maka hasil yang akan dicapai adalah adanya perasaan kompetensi dalam kemampuan intelektual, sosial, dan fisik, namun bila pada tahap ini perkembangan emosional tidak dilalui dengan baik dapat menimbulkan adanya perasaan inferioritas. ${ }^{7}$

\section{Kesimpulan dan Saran}

Pendidikan terakhir ayah responden obesitas terbanyak di perguruan tinggi sebanyak 24 orang $(60 \%)$, sedangkan pendidikan terakhir ayah responden gizi normal terbanyak didapatkan di SMA sebanyak 25 orang (55,6\%). Pendidikan terakhir ibu responden obesitas dan gizi normal terbanyak di perguruan tinggi, yaitu 25 orang $(52,1 \%)$ pada anak obesitas dan 23 orang $(47,9)$ pada anak gizi normal. Pekerjaan ayah responden obesitas terbanyak didapatkan sebagai PNS, yaitu 20 orang $(43,5 \%)$ pada anak obesitas dan 26 orang $(56,5 \%)$ pada gizi normal. Pekerjaan ibu responden terbanyak didapatkan sebagai ibu rumah tangga dan didapatkan sebanding sebanyak 21 orang $(50 \%)$ pada responden obesitas dan gizi normal. Penghasilan orang tua umumnya 
didapatkan penghasilan sangat tinggi sebanyak 60 orang $(100 \%)$, yaitu 32 orang $(53,3 \%)$ pada obesitas dan 28 orang $(46,7)$ pada gizi normal. Jumlah saudara kandung responden obesitas terbanyak didapatkan dengan jumlah saudara 2 sebanyak 18 orang $(46,2 \%)$, sedangkan paling rendah jumlah saudara 5 dan 6 sebanyak 0 (0\%). Jumlah saudara kandung terbanyak responden gizi normal adalah jumlah saudara 2 sebanyak 21 orang $(53,8 \%)$, sedangkan paling rendah yaitu dengan jumlah saudara 5 dan 6 masing-masing sebanyak 1 orang $(100 \%)$.

Persentase masalah psikososial yang dialami anak obesitas adalah 38,6\%. Persentase masalah psikososial yang dialami anak gizi normal adalah 13,6\%. Terdapat perbedaan yang bermakna masalah psikososial antara anak obesitas dan gizi normal di SD Negeri 1 Banda Sakti Kota Lhokseumawe ( $\mathrm{p}$ value $=0,015)$.

Saran dari penelitian ini adalah agar pihak SD Negeri 1 Banda Sakti Kota Lhokseumawe membuat suatu media kesehatan bagi anak dan orang tua mengenai obesitas sehingga meningkatkan pengetahuan orang tua dan dapat membekali diri dalam mencegah obesitas pada anak dan perawatan terhadap anak obesitas serta mengeluarkan kebijakan yang berhubungan dengan pengetahuan guru tentang intimidasi pada anak obesitas serta sikap membeda-bedakan antara anak obesitas dan anak gizi normal

\section{Ucapan Terima Kasih}

Penulis menyadari jurnal ini dapat terselesaikan dengan baik berkat bantuan dari berbagai pihak, oleh karena itu dengan penuh kesungguhan dan kerendahan hati penulis mengucapkan terima kasih kepada dr. Ibrahim Puteh, Sp.KJ, dr. Nur Fardian, M.Gizi, dan dr. Nora Maulina, M.Biomed.

\section{Daftar Pustaka}

1. World Health Organization. Population-based approaches to childhood obesity prevention. WHO Library Cataloguing-in-Publication Data. Geneva : World Health Organization, 2012.

2. Soetjiningsih. Tumbuh kembang anak. Jakarta : EGC, 2012.

3. World Health Organization. Who-led commission on ending childhood obesity meets to develop global responses to obesity epidemic. Geneva : World Health Organization, 2015.

4. Misnadiarly. Obesitas sebagai faktor resiko beberapa penyakit. Jakarta : Pustaka Obor Populer, 2007.

5. Sartika R. Faktor risiko obesitas pada anak usia 5-15 tahun di Indonesia. Makara Kesehatan, 2011.

6. Departemen Kesehatan. Riset kesehatan dasar 2013. Jakarta : Badan Penelitian dan Pengembangan Kesehatan Kementerian Kesehatan RI, 2013.

7. Hurlock EB. Psikologi perkembangan. Jakarta : Erlangga, 2005.

8. Dinas Pendidikan Pemuda dan Olahraga Kota Lhokseumawe. Daftar Laporan Bulanan Sekolah Dasar tahun 2015. Lhokseumawe : Dinas Pendidikan Pemuda dan Olahraga Kota Lhokseumawe, 2015.

9. Harahap DF, Sjarif DR, Soedjatmiko, Widodo DP, Tedjasaputra MS. Identification of emotional and behavior problem in obese children using Child Behavior Checklist (CBCL) and 17-items Pediatric Symptom Checklist (PSC-17), Paediatr Indones 2010; 50;1.

10. Ariani A, Sembiring T. Prevalensi obesitas pada anak usia Sekolah Dasar di Kota Medan. Majalah Kedokteran Nusantara 2007; 40;2.

11. Hadi RF, Afriwardi, Jurnalis YD. Gambaran obesitas pada siswa Sekolah 
Dasar di SD Pertiwi dan SD Negeri 03 Alai Padang. Jurnal Kesehatan Andalas;4;1.

12. Gupta N, Goel K, Shah P, Misra A. Childhood obesity in developing Countries: epidemiology, determinants, and prevention. Endocrine Reviews 2012;33;1.

13. Munawwarah, Syam A, Hendrayati, Gambaran uang saku dan pengeluaran konsumsi pangan pada penderita overweight dan obesitas mahasiswa Universitas Hasanuddin, 2013.

14. Pujiastuti E, Fadlyana E, Garna H. Perbandingan masalah psikososial pada remaja obes dan remaja gizi normal. Sari Pediatri 2013;15; 4.

15. Siregar FA. Pengaruh nilai dan jumlah anak pada keluarga terhadap norma keluarga kecil bahagia dan sejahtera (NKKBS), 2003 dilihat 1 April 2016, http://library.usu.ac.id/download/fk $\mathrm{m} / \mathrm{fkm}$-fazidah2.pdf.

16. Pramudita RA. Faktor risiko obesitas pada anak sekolah dasar di Kota Bogor.
Departemen Gizi Masyarakat. Institut Pertanian Bogor, 2011.

17. Permatasari IRI, Mayulu N, Hamel R. Analisis riwayat orang tua sebagai faktor risiko obesitas pada anak SD di Kota Manado. E-Jurnal Keperawatan 2013;1;1.

18. Janssen I, Craig WM, Boyce WF, Pickett W. Association between overweight and obesity with bullying behaviors in school-aged children. Pediatrics 2004;113,1.

19. Latzer Y, Stein D. A review of the psychological and familial perspectives of childhood obesity. Journal of Eating Disorders 2013;1;7.

20. Qiao-Zhi G, Wen-Jun M, Shao-Ping N, Yan-Jun X, Hao-Feng X, Yu-Run Z. Relationships between weight status and bullying victimization among school-aged adolescents in Guangdong Province of China. Biomedical and Environmental Sciences 2010;23;2 